\title{
https://doi.org/10.48009/1_iis_2006_373-379 \\ PRESENCE OF E-LEARNING IN SLOVENIAN HIGHER EDUCATION INSTITUTIONS
}

\author{
Mag. V. Sulčič, University of Primorska, Faculty of Management, viktorija.sulcic@ fm-kp.si \\ Dr. D. Lesjak, University of Primorska, Faculty of Management, dusan.lesjak@fm-kp.si
}

\begin{abstract}
ABSRACT
In 2003 and 2004, research on information and communication technology (ICT) presence and usage was conducted among tertiary education institutions in Slovenia. The basic purpose of the research was to draw up indicators for EU comparisons, following the requirements of Eurostat. The paper mainly presents findings from the second study, in which $85 \%$ Slovenian higher education institutions responded to the mail survey. Some interesting findings arose between private and public schools and across study fields as well. The majority of students in Slovenia study at public schools. Business studies are the most popular field for Slovenian students. Business schools are much better equipped than other schools and therefore have better conditions for e-learning. In fact, e-learning is more often used at business schools than elsewhere. The research indicated that school management is aware of the opportunities brought by e-learning and its strategic impact for the further development of institutions. Therefore, the situation in Slovenia is mature for further e-learning development.
\end{abstract}

Keywords: E-learning, ICT, Higher Education, Slovenia

\section{INTRODUCTION}

Up-to-date knowledge should be obtained by the active part of the population who has difficulty leaving their work places and going back to schools. Therefore, new ways of learning [6] have been developed in recent years. Most of them are well supported by ICT. ICT was first used as a means of delivery in distance education. Nowadays ICT is used in real classrooms, too-to present lectures, for computer-based learning, to support communication, as an information resource, etc. Different ways of learning in which ICT is used are called e-learning [4].

E-learning is becoming increasingly interesting for different institutions and organizations. Private and public educational institutions worldwide cater to the increasing demand by a variety of educational programs offering new forms of education, supported by ICT, and especially by the Internet. For example, the market of e-learning has been one of the fastest growing in North America [3].

According to the report by Eurostat (Statistical Office of the EU), the number of tertiary students increased by $17 \%$ from $1997 / 1998$ to $2002 / 2003$ [1]. The demand for different study programs also increased in our country (Table 2).

We are aware that an appropriate level of ICT equipment and its usage are two basic conditions for the introduction and implementation of e-learning, and that educational institutions (as well as the government) play a key role, as they should, in facilitating the introduction and usage of ICT. We collected and analyzed data to establish the relations between the ICT equipment and usage of ICT, especially those for e-learning proposals at higher educational institutions in Slovenia.

\section{ICT IN SLOVENIA}

Slovenia is a small European country with 2 million inhabitants situated between Italy, Austria, Hungary, and Croatia. It joined the European Union (EU) in 2004.

The comparison of ICT usage and access to the Internet between Slovenia and the EU countries is presented in Table 2. Data was collected from Eurostat Information society statistics [2], where data about student access to the Internet in 2005 for Slovenia were unreliable or uncertain. Therefore, we presented only data for 2004 .

Slovenian students are in a better position than students in other European countries. The level of Internet access of households in Slovenia and the EU 25 is the same, but we need to stress that in the EU $15,53 \%$ of households have Internet access. The statistical data for the EU 15 are higher than for the EU 25, but even then Slovenian students are in a better position regarding Internet access (EU 15 75\%). According to the data [5], 40\% of Slovenian Internet users have broadband access to the Internet (ISDN, ADSL, cable or UMTS). 
Table 2. Comparison of Internet Usage in Slovenia (SI) and EU 25 [2]

\begin{tabular}{lccc}
\hline & SI & $\begin{array}{c}\text { EU } \\
\mathbf{2 5}\end{array}$ & $\begin{array}{c}\text { Index } \\
\text { SI/EU 25 }\end{array}$ \\
\hline $\begin{array}{l}\text { Computer usage (last 3 } \\
\text { months) - all individuals } \\
\text { (2005) }\end{array}$ & $37 \%$ & $41 \%$ & 90.2 \\
$\begin{array}{l}\text { Computer usage (last 3 } \\
\text { months) - students (2005) }\end{array}$ & $72 \%$ & $68 \%$ & 105.6 \\
$\begin{array}{l}\text { Internet was accessed at } \\
\text { least once a week - all } \\
\text { individuals (2005) }\end{array}$ & $40 \%$ & $43 \%$ & 93.0 \\
$\begin{array}{l}\text { Internet was accessed at } \\
\text { least once a week - } \\
\text { students (2004) }\end{array}$ & $82 \%$ & $73 \%$ & 112.3 \\
$\begin{array}{l}\text { Level of Internet access } \\
\text { of households (2005) }\end{array}$ & $48 \%$ & $48 \%$ & 100.0 \\
\hline $\begin{array}{l}\text { EU 25 - Enlarged EU - from May 2004 the European } \\
\text { Union (EU 15) was enlarged for 10 new members. }\end{array}$
\end{tabular}

\section{METHODOLOGY}

\section{Data Collection}

Research on ICT presence in Slovenia was conducted in the framework of collecting data to establish the indicators of information society in the EU. The first study was made in May 2003 and the second in November 2004 [7]. Both research activities were based on questionnaires posted via mail to all tertiary education institutions; i.e., 84 institutions were polled in 2003 and 88 in 2004. Questionnaires were sent to the person responsible for the ICT at the institution. The institutions which did not return the questionnaires were polled by phone questionnaires in August 2003 and in January 2005. In 2004, 85\% (and in 2003, 96\%) of the institutions polled returned questionnaires. We present the data for the 2004 research, but in some parts of the paper, where comparison was important, we compared results with the previous year.

\section{Sample Characteristics}

At public and private schools, students could study at the undergraduate and postgraduate levels as fulltime or part-time students. The majority of Slovenian students $(91.8 \%)$ study at public schools. At private schools, $83 \%$ of students are part-time students.

Nearly one third of the schools (31\%) are in the area of economy and business, a quarter of them (27\%) are from technical and natural science. Nearly the same rate of schools specialized in social sciences and education (24\%). At least $10 \%$ of Slovenian students studied humanities and arts and $8 \%$ studied medicine or health care. The situation is similar in the EU 25 countries, with the exception of Denmark and Finland [1]. In Denmark, about the same proportion (a quarter) of students is enrolled in the field of health and welfare and in social science, business and law. In Finland, only $22 \%$ of students are enrolled in social sciences, business and law (ibidem).

Table 3. Students Included in the Research Based on the Study Level and means of Study

\begin{tabular}{|l|c|c|c|c|c|c|c|}
\hline \multirow{2}{*}{ Study's level } & \multicolumn{3}{|c|}{$\mathbf{2 0 0 4}$} & \multicolumn{3}{c|}{$\mathbf{2 0 0 3}$} & \multirow{2}{*}{ Index } \\
\cline { 2 - 7 } & \# of students & $\%$ & $\%$ & \# of students & $\%$ & $\%$ & $\mathbf{2 0 0 4 / 2 0 0 3}$ \\
\hline Undergraduate level & $\mathbf{1 0 4 , 9 7 2}$ & 100.0 & $\mathbf{9 2 . 1}$ & $\mathbf{9 6 , 9 0 5}$ & 100.0 & $\mathbf{9 2 . 8}$ & $\mathbf{1 0 8 . 3}$ \\
\hline Full-time study & 66,219 & 63.1 & & 62,504 & 64.5 & & 105.9 \\
\hline Part-time study & 38,753 & 36.9 & & 34,401 & 35.5 & & 112.6 \\
\hline Postgraduate level & $\mathbf{9 , 0 0 4}$ & & $\mathbf{7 . 9}$ & $\mathbf{7 , 5 2 7}$ & & $\mathbf{7 . 2}$ & $\mathbf{1 1 9 . 6}$ \\
\hline All levels & $\mathbf{1 1 3 , 9 7 6}$ & & $\mathbf{1 0 0 . 0}$ & $\mathbf{1 0 4 , 4 3 2}$ & & $\mathbf{1 0 0 . 0}$ & $\mathbf{1 0 9 . 1}$ \\
\hline
\end{tabular}

For research purposes, the percentage of staff responsible for ICT at institutions is important, too. At private schools there was a higher proportion of staff responsible for ICT $(8.2 \%)$ than at public schools $(3.1 \%)$. The differences derive from the fact that at private schools there are fewer pedagogical and research staff employed than at public schools, so the rate of ICT staff could be higher. The high rate was found at medical and health schools (7.4\%), followed by business schools (5.3\%) and schools for social sciences and education (4.7\%). Only $0.2 \%$ of staff responsible for ICT was found at schools for humanities and arts.

\section{FINDINGS AND DISCUSSION}

There exist differences between higher education institutions in Slovenia, not only in the number of students and members of ICT staff but also with regard to computer equipment, Internet usage, etc. 
Differences which are important for e-learning in Slovenia are presented bellow.

\section{Computer Equipment at Tertiary Education Institutions}

For e-learning, personal computers (PC) with access to the Internet are indispensable. In private schools $85 \%$ and in public schools $99 \%$ of computers have Internet access. On average $31 \%$ of computers are available to students.

The private schools possess more PCs per 100 students than public schools (34.0 PCs per 100 students related to $5.3 \mathrm{PCs}$ at public schools). Students at business schools have better conditions for e-learning (8.9 computers per 100 students) than students at other schools (Medical and health schools: 5.5, Social science end education: 4.3, Technical and natural science 5.9 and Humanities and arts: 3.2 )

On average, in undergraduate schools there are 5.8 computers per 100 students, which is more than in the previous year (4.7 computers per 100 students). All computers included in calculations are connected to the Internet. If we take into account computers without connections to the Internet, but available to students, there are only 6.0 computers per 100 students.

More then a half of all computers for students are located in computer rooms (53\% at public and $68 \%$ at private schools). Ninety-four percent of schools had computers in computer rooms where, on average, 29 computers could be found per room. Students could use computers during organized lessons and for individual work; e.g., for the preparation of writing assignments, searching for Internet resources, communicating with teachers and peers, working in an e-classroom, etc. In computer classes students mostly work in groups, whereas in other places they work individually or in small groups.

\section{Internet Access and Computer Networks}

The majority of schools ( $84 \%$ of public and $56 \%$ of private schools) accessed Internet through the public institution ARNES - Academic and Research Network of Slovenia (www.arnes.si). ARNES is a provider that offers cable access to the Internet. The second most popular Internet provider (39\% of public and $86 \%$ of private schools) is SiOL (company.siol.net) which offers ADSL and ISDN Internet access. Some schools have more than one way of gaining access to the Internet. Some new Internet providers with new technology are entering the market (T2 technology), but their services have not been widely spread yet.

Some schools have more local networks (LANs). More LANs are installed at public (3.3) than private schools (1.9), which are related to the fact that public schools are bigger, have more students and therefore more computers even if the ratio of computers per 100 students seems worse than at private schools. The nature of study at medical and health care schools demands different separated LANs (4.7). More LANs at medical and health care schools necessitate a larger ICT staff.

\section{Supporting Administrative Processes}

A set of questions was dedicated to ways of using ICT at schools which can support administration and/or teaching.

The most popular ICT usage is electronic registration for exams (Table 4). Electronic assessments are less widespread at our schools, other than business, and social science and education schools. ICT usage, mainly for administrative purposes, is presented in Table 4.

Table 4. ICT Usage for Administrative Purposes All Schools

\begin{tabular}{|c|c|c|c|c|c|}
\hline \# & $\begin{array}{l}\text { Students could use ICT } \\
\text { at school .... }\end{array}$ & $\begin{array}{l}\text { To } \\
\%\end{array}$ & $\begin{array}{l}\mathbf{P a} \\
\%\end{array}$ & $\begin{array}{l}\text { No } \\
\%\end{array}$ & $\begin{array}{l}\mathbf{P I} \\
\%\end{array}$ \\
\hline 1 & ...to register for exams. & 74 & 5 & 9 & 12 \\
\hline 2 & $\begin{array}{l}\text {..to inform themselves } \\
\text { about exam results via e- } \\
\text { mail }\end{array}$ & 22 & 12 & 48 & 18 \\
\hline 3 & $\begin{array}{l}\text {...to inform themselves } \\
\text { about exam results via } \\
\text { SMS }\end{array}$ & 15 & 4 & 73 & 8 \\
\hline 4 & $\begin{array}{l}\text {...to look into their exam } \\
\text { records }\end{array}$ & 66 & 7 & 18 & 9 \\
\hline 5 & $\begin{array}{l}\text {...for enrolment through } \\
\text { the Internet. }\end{array}$ & 20 & 15 & 53 & 12 \\
\hline 6 & $\begin{array}{l}\text {...for sitting for exams } \\
\text { electronically. }\end{array}$ & 6 & 8 & 74 & 12 \\
\hline 7 & $\begin{array}{l}\text {...for ordering different } \\
\text { forms electronically. }\end{array}$ & 31 & 12 & 47 & 10 \\
\hline 8 & $\begin{array}{l}\text {...to communicate with } \\
\text { peers through forums. }\end{array}$ & 42 & 7 & 32 & 19 \\
\hline 9 & $\begin{array}{l}\text {..to have wireless } \\
\text { (WLAN) access to the } \\
\text { Internet. }\end{array}$ & 18 & 3 & 57 & 22 \\
\hline
\end{tabular}

Legend: To - totally, $\mathrm{Pa}$ - partly, Pl - planner 
Table 5. Web pages at schools of tertiary education

\begin{tabular}{llccc}
\hline \multirow{2}{*}{ Schools } & & $\begin{array}{c}\text { Static web pages } \\
(\%)\end{array}$ & $\begin{array}{c}\text { Up-to-date web } \\
\text { pages }(\%)\end{array}$ & $\begin{array}{c}\text { Interactive web pages } \\
(\%)\end{array}$ \\
\hline Ownership & Public & 67 & 44 & 16 \\
& Private & 75 & 75 & 31 \\
\hline Study & Medicine and health care & 67 & 33 & 0 \\
field & Social sciences and education & 72 & 56 & 30 \\
& Business & 70 & 52 & 15 \\
& Technical and natural science & 71 & 44 & 17 \\
& Humanities and arts & 61 & 64 & 30 \\
\hline & Average & $\mathbf{6 9}$ & $\mathbf{5 2}$ & $\mathbf{2 0}$ \\
\hline
\end{tabular}

Thirty-four percent of teachers and assistants own upto-date personal web pages $(40 \%$ at public schools and $16 \%$ at private schools). In more than half $(55 \%)$ of the schools, the process of renewal or integration of school information systems was performed at the time of the survey.

\section{Supporting Education and Learning Processes}

One of the easiest ways of using ICT for supporting learning process is to prepare web pages on which students can find information about courses. Web pages may be very simple or sophisticated - they give the capacity to support communication among students. We formed three groups of web pages, which questions in the questionnaires targeted:

- Similar static web pages with basic information about the course.
- Up-to-date web pages.

- Interactive web pages, which offer students some interaction.

From Table 4, it is obvious that far fewer web pages are interactive.

The next step of using ICT in the learning process is to offer some courses through the Internet - through an interactive web page or through learning management systems.

Questions about e-learning or distance learning did not make elicit answers differentiating between performing single courses or a whole program online. So in Table 5 all schools are included - those which perform only a single course and those which carried out all courses online.

Table 6. ICT Usage for E-learning Courses

\begin{tabular}{|c|c|c|c|c|c|c|c|c|c|c|}
\hline \multirow{3}{*}{ Schools } & & \multicolumn{6}{|c|}{ Undergraduate level } & \multirow{2}{*}{\multicolumn{3}{|c|}{ Postgraduate level }} \\
\hline & & \multicolumn{3}{|c|}{ Full-time study } & \multicolumn{3}{|c|}{ Part-time study } & & & \\
\hline & & Yes & No & Planned & Yes & No & Planned & Yes & No & Planned \\
\hline \multirow[t]{2}{*}{ Ownership } & Public & 15 & 64 & 15 & 15 & 62 & 23 & 10 & 74 & 16 \\
\hline & Private & 6 & 88 & 6 & 17 & 72 & 11 & 6 & 82 & 12 \\
\hline \multirow[t]{5}{*}{ Study field } & Medicine and health care & 0 & 80 & 0 & 0 & 80 & 20 & 0 & 80 & 20 \\
\hline & Social science and education & 13 & 67 & 13 & 13 & 62 & 25 & 0 & 76 & 21 \\
\hline & Business & 21 & 67 & 21 & 29 & 54 & 17 & 14 & 77 & 9 \\
\hline & Technical and natural science & 11 & 72 & 11 & 11 & 72 & 17 & 11 & 78 & 11 \\
\hline & Humanities and arts & 0 & 75 & 0 & 0 & 75 & 25 & 11 & 67 & 22 \\
\hline
\end{tabular}

While more full-time undergraduate e-learning courses are offered at public schools (15\% of all fulltime courses), a bit more part-time undergraduate elearning courses are offered at private schools.
Undergraduate students at medical and health care schools could not be enrolled in any e-learning course, so they could not obtain any experience regarding e-learning at all. Students at humanities 
and arts could be enrolled in some courses only at the postgraduate level. Students at business schools are in the best position again. Statements about elearning were assessed on a five degree scale (5=totally agree, $1=$ totally disagree).

Table 7. Statements about E-learning

\begin{tabular}{lc}
\hline \multicolumn{1}{c}{ Statements } & M \\
\hline $\begin{array}{l}\text { E-learning is crucial for the development of our } \\
\text { institution. }\end{array}$ & 3.7 \\
$\begin{array}{l}\text { E-learning is more suitable for postgraduate } \\
\text { study. }\end{array}$ & 2.8 \\
$\begin{array}{l}\text { E-learning is more suitable for part-time study. } \\
\text { We are aware of opportunities that e-learning }\end{array}$ & 3.4 \\
$\begin{array}{l}\text { could offer to our institution. } \\
\text { We are behind other institutions in the field of }\end{array}$ & 2.4 \\
e-learning. & \\
$\begin{array}{l}\text { E-learning is not suitable for our institution. } \\
\text { There is a lack of staff to introduce e-learning } \\
\text { at our institution. }\end{array}$ & 1.7 \\
$\begin{array}{l}\text { There is a lack of equipment to introduce e- } \\
\text { learning at our institution. }\end{array}$ & 3.3 \\
$\begin{array}{l}\text { We need more information about e-learning. } \\
\text { We wish there were more coordination }\end{array}$ & 3.3 \\
regarding e-learning on the national level. & 3.6 \\
\hline
\end{tabular}

$$
\mathrm{M}=\text { Average }
$$

The analysis of data shows that understanding of the term e-learning differs from school to school. While for some, a virtual classroom is needed for elearning; for others, web pages are enough to be placed in the group of schools which offer e-learning. Regardless, it is interesting what the management at schools thinks about e-learning.

The opinion about the potential of ICT usage is also important for introducing e-learning. Statements about ICT impact were assessed on a five degree scale (5=ICT usage will improve process/activity significantly, $1=\mathrm{ICT}$ usage does not bring any improvement on process/activity). The average assessment is presented in Table 8 .

The management is aware of the potential opportunities through the use of e-learning and its strategic impact for further development of institutions. That is stimulating for further development of e-learning despite the fact that not all institutions are properly equipped with ICT.
Table 8. Opinion about ICT Impact on Institutional Processes and Activities

\begin{tabular}{lc}
\hline \multicolumn{1}{c}{ ICT will improve a/an process/activity } & M \\
\hline Educational process & 3.9 \\
Research activities & 4.1 \\
Administrative activities & 4.0 \\
Managerial activities & 3.8 \\
Relationship with institutional environment & 3.9 \\
\hline \multicolumn{2}{c}{ M = Average }
\end{tabular}

In Slovenia, there are only a few institutions which offer distance education for their whole program $4 \%$ of public institutions' full-time studies (schools for technical and natural science and social sciences and education). The same rate of public schools offer distance education for part-time studies, too, but in this case, schools mainly educate in business. Parttime distance study is offered by private schools, too (18\% of programs are offered in such a way).

\section{CONCLUSION}

As seen from the research results and their comparison with research results available for the EU, Slovenian tertiary education institutions are, on average, not well and appropriately equipped with ICT (especially with regard to a rather limited number of PCs per students). That is only one of the reasons that educational institutions are currently unable to effectively develop, introduce and provide their study and educational programs in the form of e-learning. This especially applies to computer applications used in e-learning, especially at public institutions in the area of social sciences and humanities.

But what is important is that school management is aware of the potential of ICT usage in all school processes, which could be a good sign for further development of e-learning. It is true that the potential is mainly seen in research and administrative processes. But the introduction of ICT in education is similar to the introduction of ICT in companies; it demands a renewal of educational, administrative and managerial processes, which is an organizational and managerial problem. Therefore management awareness of potential of ICT usage is quite important.

For the development of e-learning, there is cause for optimism in that students in Slovenia use computers and the Internet more frequently than the average student in the EU 25. Based on the level of Internet access of households where Slovenian households are 
at the same level as EU 25 households, the possibilities to access online courses are given. If public schools do not offer courses, the market is open for private initiative-national and international.

For Slovenia, given its small size, a blended learning approach of e-learning is more suitable and more acceptable for higher educational institutions than an Internet distance education approach. Therefore the institutional level of ICT equipment is especially important.

\section{REFERENCES}

1. Andren, B. (2005). Population and social conditions - Education and training. Statistics in Focus. (19), Eurostat.

2. Eurostat. (2006). Data Explorer. Available : http://epp.eurostat.cec.eu.int/portal/page?_pageid $=1090,30070682,1090 \_30298591 \& \_$dad=portal \&_schema=PORTAL [19. $-29.1 .2006]$.

3. HKGCC - Hong Kong General Chamber of Commerce. Edport.com. Available: http://www.chamber.org.hk/info/member_a_wee k/edport.asp_[2. 6. 2002].

4. InternetTime Group. Available: http://www.Internettime.com/ [2. 6. 2002].

5. SURS - Statistični urad Republike Slovenije. (2006). Informacijska družba. V Stastične informacije - štev. 6, 9. 1. 2006. Available: http://www.ris.org/uploadi/editor/1136816556S URSgospodinjstva2005.pdf [19. 1. 2006].

6. Trunk Širca, N. \& Sulčič, V. (2003). Lifelong learning and higher education institutions: Through implemented example to systemic solution. Knowledge Society - Challenges to Management / 4th International Conference of the Faculty of Management Koper, University of Primorska, 20-22 Nov. 2003, Portorož. - Koper, 69-78.

7. Vehovar V., Lesjak, D., Sulčič, V. \& Pehan V. (2005). RIS - informacijske tehnologije 2004/2005 - visokošolski in višješolski zavodi. Available: http://www.ris.org [5. 1. 2006]. 